\title{
COOPETITION STRATEGY: THE INFLUENCE OF EXTERNAL WORKPLACE AND TECHNOLOGY FLEXIBILITIES
}

\author{
Angel Martínez-SÁNCHEZ \\ Silvia Abella-GARCÉS \\ Manuela Pérez-PÉREZ \\ María-José Vela-JIMÉNEZ \\ University of Zaragoza, Spain
}

\begin{abstract}
This paper analyses the relationship between human resource flexibility and coopetition in a sample of Spanish manufacturing firms. Using data from a panel of 1,626 Spanish industrial firms in the period of 2003-2006, the paper tests a model of research hypotheses and analyses the differences of firms characteristics and technological strategy among coopetition and non-coopetition firms.
\end{abstract}

Keywords: Human Resources Flexibility; Innovation; Coopetition; Technological Cooperation. Technology Outsourcing.

\section{INTRODUCTION}

Coopetition, the strategic phenomenon in which firms engage in simultaneous cooperation and competition with each other (Nalebuff and Brandenburger, 1996), is intriguing in theoretical as well as practical terms (Gnyawali et al., 2006). Although some scholars suggest that collaboration among rivals may inhibit competition by facilitating collusion or by shaping industry structure in anticompetitive ways, others suggest that firms derive valuable resources from other collaborative-competitive relationships and strengthen their competitive capabilities (Gnyawali and Madhavan, 2001).

The findings of existing studies on coopetition and innovation imply that relationships between competing firms include unique characteristics that are lacking in relationships between non-competitors, and that these characteristics might product different results in terms of innovation. However, despite the growing relevance of the topic, the development of theoretical frameworks for innovation-related coopetition is still in an emergent phase (Ritala and Hurmelinna-Laukkanen, 2009). Our aim in this study is to address this gap, and to focus on the question of how innovation-related coopetition differs from non-coopetition in terms of some flexibility dimensions related to human resources and to the network process of accessing and deploying knowledge within the firm.

\section{THEORY AND HYPOTHESES}

According to the knowledge-based view, a firm gains a competitive advantage by exploring, exploiting, and integrating different specialized knowledge areas through internal $R \& D$ activities and external technology sources (Grant, 1996). Focusing on in-house R\&D activities allows a firm to develop its core technological capabilities and experience higher economic returns while allowing for better control and tacit knowledge understanding embedded in the development process (Kessler et al., 2000). Alternatively, a firm should implement external technology sourcing to broaden its existing technological knowledge base, keep abreast of cutting-edge technologies, and remain flexible (Grant, 1996).

The existing literature addresses various modes of external technology acquisition. These modes include cooperative agreements, $R \& D$ outsourcing, inward technology licensing, and mergers and acquisitions. This paper focuses on $\mathrm{R} \& \mathrm{D}$ cooperation and outsourcing because they are more related to organizational flexibility. First, firms can improve their technological innovation by collaborating 
with competent competitors (Tether, 2002). By sharing technological knowledge and skills, firms involved in this type of cooperative agreement may create a synergistic effect on new knowledge creation (Inkpen and Pien, 2006). A firm collaborating with its competitors may therefore gain better innovation performance than by working alone. Using this approach, firms can simultaneously accelerate their capability development and reduce technological innovation time and risk. Furthermore, collaboration provides a good opportunity to firms to measure their competitors' technological levels. Firms that are more knowledgeable about their competitors' technology strategies are better able to differentiate themselves from their competitors. Firms can also learn lessons from their competitors' technological innovation mistakes or problems.

Coopetition creates value through cooperation between competing organizations, aligning different interests toward a common objective and helping to create opportunities for competitive advantage by removing external obstacles and neutralizing threats. It implies that organizations can interact in rivalry due to conflicting interests and at the same time cooperate due to common interests. Firms that engage in coopetition ties find themselves gradually enmeshed in a network of crosscutting ties. Consistent with well-established network arguments, such firms derive several benefits from their coopetition network, such as easier and earlier access to a large volume of network resources, earlier knowledge of important developments in the industry, and ability to control information and resource flows in the network. The existence of simultaneous cooperative and competitive relations possesses a unique dynamic that is just beginning to be understood (Ketchen et al., 2004).

The most prominent theoretical and conceptual approach to coopetition and innovation includes arguments from game theory, the resource-based view (RBV) and capability theory, and transaction cost economics (see Lado et al., 1997; Quintana-García and Benavides-Velasco, 2004, for a thorough discussion on coopetition from these perspectives). According to these views, competitors are sometimes in a position to engage in positive-sum games that create value for all participants (the game-theoretic perspective). Further, competitors sometimes possess similar knowledge and a common market vision, which helps them to engage in such collaboration (the RBV perspective). Conversely, from the perspective of transaction cost economics coopetition is considered an extremely risky business because competitors have individual business incentives that might lead to opportunistic behaviour.

Regarding flexibility, the most frequent approach to analyse flexibility in organizations is the RBV and capability theory. Competitive behaviour depends not only on the firm's ability to exploit its resources but on exploring new not yet existing or at least fully realized dynamic capabilities (Rothaermel and Hess, 2007). Flexibility options have the potential to broaden the range of capabilities necessary to innovate. Wright and Snell (1998) define flexibility as a firm's ability to quickly reconfigure resources and activities in response to environmental demands. To attain the level of flexibility that customers value. This paper focuses on the influence of external workplace and technology flexibility on coopetition because this flexibility is more related to the firm's inter-organizational cooperation and to the process of accessing and deployment of knowledge in the firm that may influence more strongly the innovation process and the competitive behaviour of the firm.

Much of a firm's innovation now occurs in conjunction with other firms (competitors, customers \& suppliers) rather than inside the firm because the increasing complexity of markets makes difficult for firms to have all of the resources necessary to innovate. Since developments in non-core knowledge areas have become very rapid, it is no longer feasible to keep up with all of these knowledge areas in as much detail as needed (Quinn, 2000). External sources of knowledge are sometimes the only option for firms that wish to keep up-to-date. Prior research suggests that the use of flexible employment contracts or outsourcing may be perfectly compatible with the achievement of innovation in dynamic and high-technology environments to ensure the presence of knowledge resources that may be beyond existing internal capabilities (Matusik and Hill, 1998; Nesheim, 2003).

Exhibit 1 depicts the research model. The next paragraphs develop the research hypotheses. We propose that several workplace flexibility practices are positively related to coopetition: temporary employment, hire of R\&D employees, and R\&D outsourcing. Two more technological flexibility dimensions are also proposed to be positively related to coopetition: financial participation in innovative firms, and technological cooperation with customers and suppliers. The purpose of this research is to contribute to develop theoretical frameworks for innovation-related coopetition. Recent studies find that flexibility dimensions are relevant to analyse the firm's competitive behaviour of firms in the innovation field (e.g., Martínez-Sánchez et al., 2009). 
Exhibit 1. Research Model

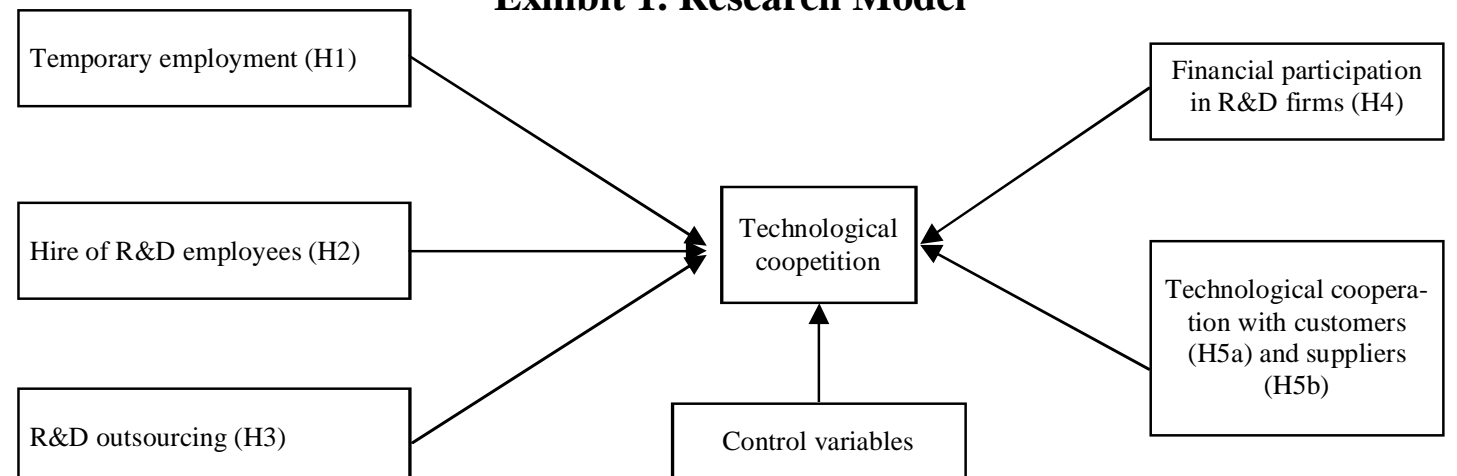

First, temporary employment is an external flexibility dimension that contributes to adjust the stock of employees and skills in a dynamic environment. Dynamic environments are characterized by variations in product demand but also in technologies and in customer preferences. When the firm's operating environment is highly dynamic, previously developed capabilities may not be able to keep up with the frequent changes in technological conditions. The misfit between a firm's existing capabilities and the firm's operational environment may be mitigated if the firm has flexibility to explore new areas and build new capabilities. The use of temporary employment opens new possibilities to firms that cooperate technologically with competitors. Training, recruitment, and hiring costs are lower for temporary than for permanent employees, and firms can manage capacity more efficiently (Kalleberg and Mardsen, 2005). On the other hand, firms may also develop flexibility capabilities by accessing, creating, and implementing 'new knowledge'. Therefore, the use of temporary employment in innovative activities may facilitate the competitive behaviour related to coopetition.

Hypothesis 1. The percentage of temporary employment in the workforce is positively related to technological coopetition.

Firms may also need access to relevant external knowledge through specialised R\&D employees who bring knowledge of occupational and industry best practices into the firm. External knowledge may leverage the internal stock of knowledge to develop innovations in order to overcome greater environmental uncertainty. Nesheim (2003) and Nesheim et al. (2007) found that firms use external personnel and consulting firms in core value-creation areas to bring knowledge and industry 'best-practices' into the firm. Compared with others, firms that hire R\&D experts are more likely to benefit from specialized knowledge that complements in-house expertise by acquiring, processing, and using diverse information and resources and in turn undertaking a wide range of competitive activities that favour coopetition. Therefore, firms that incorporate $R \& D$ experts are in a better position to establish cooperative relationships with competitors because they are able to advance in new technological fields and complement the stock of knowledge of core employees in the coopetition firms.

Hypothesis 2. The use of external $R \& D$ employees is positively related to technological coopetition.

The outsourcing of some innovative activities may also bring new knowledge and complement innovation capabilities of core employees in firms who cooperate technologically with competitors. When properly planned and executed, firms that outsource R\&D reduce innovation process obstacles and maximize innovation and overall company performance (Gupta et al., 2009; Huang et al., 2009; Watanabe and Hur, 2004). In addition, R\&D outsourcing can be treated as an external learning process and has direct implications regarding how effectively firms can apply existing knowledge from outside sources to produce innovation performance (Kessler et al., 2000). Mol et al. (2004) find that during periods of increased product innovation, firms intensify their global searching activity to obtain and combine knowledge from various specialised sources. Similarly, firms that conduct their own R\&D and seek external knowledge related to their core competences can more effectively incorporate this external knowledge and use it to enhance the innovation needed in coopetition (Bierly et al., 2009). Thus, we propose:

Hypothesis H3. The outsourcing of $R \& D$ activities is positively related to technological coopetition. 
Cooperative ties with competitors provide a firm with opportunities to learn about its partners and afford access to resources residing in the network. Gnyawali and Madhavan (2001) suggested that network resources are critical in shaping a firm's competitive behaviour. Firms with a superior position in their networks are likely to learn about competitive opportunities sooner and use that knowledge in planning and executing competitive actions. Structurally advantaged firms have more opportunities to learn about the capabilities of other firms in the network, have greater flexibility to take action based on such knowledge, and can draw key assets from the network with less difficulty. A source of superior advantages for firms in network relationships is the financial participation in R\&D firms that develop technological innovations. This access to external knowledge enables the firm to stay in a better position to cooperate with competitors because on-going R\&D projects provide the edge to advance the technological fields that create value and new markets. Thus, we propose:

Hypothesis H4. The financial participation in firms that develop technological innovations is positively related to technological coopetition.

The empirical studies that have focused on the connection between different collaborative R\&D partners and innovative performance provide evidence of the fact that competitors differ from other kinds of collaboration partners in innovation, and that cooperation between competitors contributes more to creating completely new products than cooperation between non-competing firms (Quintana-García and Benavides-Velasco, 2004; Tether, 2002). According to the game theory, coopetition is rational when cooperating with a competitor increases the size of the market so that there is more to allocate among the participants than there would be otherwise. With respect to innovation activities, this intuition seems to be particularly applicable. Creating new product and services or improving current ones in collaboration with competitors may increase the size of the current market or create completely new ones. This leaves the collaborating competitors better off than if they had not been collaborating.

Research suggests that the more competitive actions a firm undertakes or the more competitively aggressive the firm is, the more likely that it will increase market share and profitability, and improve its competitive advantage (Young et al., 1996). Thus, firms that cooperate technologically with customers and suppliers have broader learning opportunities as they are exposed to a large amount of information from diverse environments. Such firms may be more externally oriented and can take advantage of external resources more efficiently.

Suppliers usually have greater expertise and better knowledge of components and parts that are critical to a firm's technological development. Their expertise and different perspectives may make it easier for a firm to create new product development methods and to identify potential technical problems and increasingly difficult and costly design changes (Kessler and Chakrabatri, 1996). Collaborating with customers is also important because it helps to identify technology development market opportunities and reduces the likelihood of poor design in the early stages of development (Brockhoff, 2003). Consequently, firms that cooperate technologically with customers and suppliers are likely to possess the internal capabilities needed to use network resources more efficiently and effectively and therefore benefit more from cooperating with competitors and increasing the size of the market through coopetition.

Hypothesis H5a. Technological cooperation with customers is positively related to technological coopetition.

Hypothesis H5b. Technological cooperation with suppliers is positively related to technological coopetition.

\section{METHODS}

In order to test these hypotheses, we conducted an empirical study on Spanish industrial firms. We use the Survey of Business Strategies (SBS) questionnaire which contains a set of statements that permit the study of competitive behaviour for a great number of Spanish industrial firms. The SBS is an annual survey conducted by the SEPI Foundation in collaboration with the Spanish Ministry of Industry with the objective of knowing the evolution of the characteristics and strategies of Spanish industrial firms. This survey contains information about markets, customers, products, employment, technological activities and economic-financial data of the firms. The reference population comprises industrial firms operating in Spain and with more than 10 employees, with representativeness being one of its characteristics. We develop a database with panel data from 1,367 industrial firms in the period 20032006. 
The research hypotheses were tested through logistic regression analysis. The dependent variable in the study is a dummy variable that indicates if the company cooperates technologically with competitors. The independent variables are:

- Four measures of external flexibility: the percentage of temporary employees in the workforce, the hire of employees with R\&D experience (dummy), the outsourcing of R\&D activities (dummy), and the financial participation in firms that are developing technological innovations (dummy).

- Two dummies of technological cooperation in the supply chain with customers and suppliers.

The regression analysis controls for: firm size (logarithm of sales) because firm size is widely accepted as a predictor of competitive behaviour (e.g., Miller and Chen, 1996); R\&D effort (percentage of R\&D employees in the workforce); firm's performance (return on sales) as previous performance is likely to influence competitive behaviour (Young et al., 1996); identity between firm ownership and control (dummy), and industry. Before the multivariate analysis, a comparative study was also carried out to study differences between coopetition and non-coopetition firms. Contingency analysis and means comparisons (t-test) are used in this descriptive study.

\section{RESULTS}

Coopetition is a marginal strategy among Spanish manufacturing firms. Only $2.63 \%$ of companies cooperated technologically with competitors in the period 2003-2006, whereas technological cooperation with suppliers (21.24\%), customers (18.03\%), and R\&D centres (22.26\%) is more widespread. Nevertheless, coopetition is positively associated to these other forms of technological cooperation. Exhibit 2 indicates several contingency indicators between coopetition and technological cooperation with suppliers, customers and R\&D centres. The results indicate that coopetition is positively associated to other forms of technological cooperation in the value added chain: firms that cooperate technologically with competitors also cooperate with suppliers (82.95\%), customers (76.13\%) and R\&D centres $(86.93 \%)$.

\section{Exhibit 2. Contingency Indicators of Association between Coopetition and Other Forms of Technological Cooperation in The Supply or Value Added Chain}

\begin{tabular}{|l|r|r|r|}
\hline & \multicolumn{1}{|c|}{ Suppliers } & \multicolumn{1}{c|}{ Customers } & \multicolumn{1}{c|}{ R\&D centres } \\
\hline Chi-square Pearson & $411,345^{* * * *}$ & $412,870^{* * * *}$ & $436,769^{* * * *}$ \\
Continuity Correction & $407,566^{* * * *}$ & $408,843^{* * * *}$ & $432,940^{* * * *}$ \\
Likelihood Ratio & $316,941^{* * *}$ & $293,486^{* * *}$ & $346,516^{* * * *}$ \\
Phi Statistic & $0.248^{* * *}$ & $0.248^{* * * *}$ & $0.256^{* * * *}$ \\
\hline
\end{tabular}

$+\mathrm{p}<0.1 \quad * \mathrm{p}<0.05 \quad * * \mathrm{p}<0.01 \quad * * * \mathrm{p}<0.001$

The percentage of coopetition firms increases in the sample of innovative firms. Considering only those firms ( $21 \%$ of total firms) that have developed at least 1 product innovation in the surveyed period, 6.23 per cent cooperated technologically with competitors. The percentage of coopetition firms is also higher $(5.56 \%)$ in the sample of firms that have developed at least 1 process innovation in the surveyed period (27\% of total firms). Similarly, the percentage of coopetition firms in the group of patenting firms $(6.3 \%$ of total firms) is much higher $(51 \%)$ than among non-coopetition firms. The contingency indicators for these sub-samples of firms also show that coopetition is positively associated to other types of technological cooperation and that cooperation with suppliers, customers and R\&D centres is higher among coopetition firms and the differences are statistically significant $(\mathrm{p}<0.001)$. The percentages of coopetition firms that also cooperate with suppliers, customers and R\&D centres are similar to the percentages in the total sample; for instance product innovative firms that cooperate technologically with competitors also cooperate with suppliers (79.5\%), customers (75\%) and R\&D centres (90.9\%).

Exhibits 3, 4 \& 5 show mean differences (t-test) of several characteristics of the firm: organization (size, age, employment type,...), innovation inputs, and innovation outputs. Exhibit 3 shows the differences of organizational variables. The statistically significant results indicate that coopetition firms are larger, older and more foreign-owned than non-coopetition firms $(\mathrm{p}<0.001)$. They are also highly 
dynamic and exporting firms and use more intensively their production capacity. Exhibit 4a indicates that coopetition firms invest more resources in $R \& D$ activities and have a higher percentage of $R \& D$ employees than non-coopetition firms. These differences are also found for those firms with positive R\&D inputs (Exhibit 4b); however the difference between coopetition and non-coopetition firms is now significant for the percentage of equipment expenditures on sales: coopetition firms invest less intensively in equipment than non-coopetition firms. Regarding innovation outputs, Exhibit 5a shows that coopetition firms are more innovative than non-coopetition firms because they obtain more patents and product innovations; however Exhibit $5 \mathrm{~b}$ indicates that these differences are less statistically significant for those firms with positive $\mathrm{R} \& \mathrm{D}$ outputs, and even the number of product innovations is lower in coopetition than in non-coopetition firms.

\begin{tabular}{|l|r|r|}
\hline \multicolumn{3}{|c|}{$\begin{array}{c}\text { Exhibit 3. Mean Differences (T-Test) of Several Organizational } \\
\text { Variables between Coopetition and Non-Coopetition Firms }\end{array}$} \\
\hline & Non-coopetition firms & Coopetition firms \\
\hline Firm sales (thousand euros) & 68,574 & $310,000^{* * *}$ \\
\hline Total employees & 233 & $1,037^{* * *}$ \\
\hline Firm age & 30.6 & $41.3^{* * *}$ \\
\hline Percentage of foreign capital & 16.07 & $41.19^{* * *}$ \\
\hline ROA (return on assets - percentage) & 8.51 & 8.97 \\
\hline Export intensity & 18.87 & $34.50^{* * *}$ \\
\hline Capacity utilization & 82.9 & $87.2^{* * *}$ \\
\hline Market dynamism & 52.7 & $68.7^{* * *}$ \\
\hline Percentage of temporary employment & 13.94 & 14.10 \\
\hline Percentage of agency workers & 3.79 & 2.46 \\
\hline Percentage of full-time permanent contracts & 80.01 & $84.23^{* *}$ \\
\hline Percentage of part-time permanent contracts & 2.02 & $1.11^{*}$ \\
\hline
\end{tabular}

$+p<0.1 \quad * p<0.05 \quad * * p<0.01 \quad * * * p<0.001$

\begin{tabular}{|l|r|r|}
\hline \multicolumn{3}{|c|}{ Exhibit 4A. Mean Differences (T-Test) of R\&D Inputs (All Firms) } \\
\hline & Non-coopetition firms & Coopetition firms \\
\hline Percentage of in-house R\&D on sales & 0.63 & $2.39^{* * *}$ \\
\hline Percentage of external R\&D on sales & 0.23 & $1.39^{* * *}$ \\
\hline Percentage of R\&D employees & 1.65 & $6.42^{* * *}$ \\
\hline Percentage of equipment expenditures on sales & 0.9 & 0.65 \\
\hline
\end{tabular}

\begin{tabular}{|l|r|r|}
\hline \multicolumn{3}{|c|}{$\begin{array}{c}\text { Exhibit 4B. Mean Differences (T-Test) of R\&D Inputs } \\
\text { (Only Firms with Positive R\&D Inputs) }\end{array}$} \\
\hline & Non-coopetition firms & Coopetition firms \\
\hline Percentage of in-house R\&D on sales & 2.18 & 2.58 \\
\hline Percentage of external R\&D on sales & 1.03 & $1.72^{*}$ \\
\hline Percentage of R\&D employees & 5.37 & $7.40^{* *}$ \\
\hline Percentage of equipment expenditures on sales & 4.05 & $1.59^{* *}$ \\
\hline
\end{tabular}




\begin{tabular}{|l|r|r|}
\hline \multicolumn{2}{|c|}{ Exhibit 5A. Mean Differences (T-Test) of R\&D Inputs Outputs (All Firms) } \\
\hline & Non-coopetition firms & Coopetition firms \\
\hline Number of product innovations & 1.76 & $2.64+$ \\
\hline Number of national patents granted & 0.17 & $0.52^{* * *}$ \\
\hline Number of international patents granted & 0.24 & $2.90^{* * *}$ \\
\hline Number of total patents granted & 0.41 & $3.42^{* * *}$ \\
\hline Number of total patents/Number of product innovations & 0.33 & $2.94^{* * *}$ \\
\hline
\end{tabular}

\section{Exhibit 5B. Mean Differences (T-Test) of R\&D Inputs Outputs (Only Firms with Positive R\&D Outputs)}

\begin{tabular}{|l|r|r|}
\hline & Non-coopetition firms & Coopetition firms \\
\hline Number of product innovations & 9.25 & $5.63^{* *}$ \\
\hline Number of national patents granted & 3.23 & 2.71 \\
\hline Number of international patents granted & 7.29 & $20.40^{*}$ \\
\hline Number of total patents granted & 6.98 & $14.68^{*}$ \\
\hline Number of total patents/Number of product innovations & 2.07 & $10.13^{* *}$ \\
\hline
\end{tabular}

$+\mathrm{p}<0.1 \quad * \mathrm{p}<0.05 \quad * * \mathrm{p}<0.01 \quad * * * \mathrm{p}<0.001$

Exhibit 6 indicates contingency indicators of the association between coopetition and different types of product innovation. All types of product innovation are significant and positively associated to coopetition. However, only $50 \%$ of coopetition firms have developed product innovations in the surveyed period although this percentage is greater than among non-coopetition firms $(20.3 \%)$. In the sample of coopetition firms that develop product innovations, the main type of product innovation is new design (79.76\%), followed by new functions (61.9\%), new components $(55.8 \%)$ and new materials $(50 \%)$.

\section{Exhibit 6. Contingency Indicators of Association between Coopetition and} Different Types of Product Innovation

\begin{tabular}{|l|r|r|r|r|}
\hline & \multicolumn{1}{|c|}{$\begin{array}{c}\text { New } \\
\text { components }\end{array}$} & New design & \multicolumn{1}{c|}{$\begin{array}{c}\text { New } \\
\text { functions }\end{array}$} & \multicolumn{1}{c|}{$\begin{array}{c}\text { New } \\
\text { materials }\end{array}$} \\
\hline Chi-square Pearson & $91.908^{* * *}$ & $87,361 * * *$ & $98,794 * * *$ & $84,307 * * *$ \\
Continuity Correction & $73,597 * * *$ & $70,080^{* * * *}$ & $75,213 * * *$ & $68,655^{* * *}$ \\
Likelihood Ratio & $89,090^{* * *}$ & $86,808^{* * * *}$ & $98,701 * * *$ & $70,762^{* * * *}$ \\
Phi Statistic & $0.117 * * *$ & $0.114 * * *$ & $0.122 * * *$ & $0.112^{* * * *}$ \\
\hline
\end{tabular}

$+\mathrm{p}<0.1 \quad * \mathrm{p}<0.05 \quad * * \mathrm{p}<0.01 \quad * * * \mathrm{p}<0.001$

Exhibit 7 shows that there are some statistically significant differences of types of product innovation among product innovative firms, according to the type of external cooperation. There is a larger percentage of product innovative firms that use several types of product innovation among the group of cooperation firms (columns 'Yes' in Exhibit 6). Technological cooperation with customers introduces more statistically significant differences than other forms of external cooperation. Coopetition only produces significant differences for the type of product innovation based on new functions. 


\begin{tabular}{|c|c|c|c|c|c|c|c|c|}
\hline \multicolumn{9}{|c|}{$\begin{array}{c}\text { Exhibit 7. Mean Differences of Percentage of Product Innovative Firms } \\
\text { According to the Source of Product Innovation and The Type of } \\
\text { Technological Cooperation in the Supply Chain }\end{array}$} \\
\hline & \multicolumn{2}{|c|}{ Coopetition } & \multicolumn{2}{|c|}{ Customers } & \multicolumn{2}{|c|}{ Suppliers } & \multicolumn{2}{|c|}{ R\&D Centres } \\
\hline & No & Yes & No & Yes & No & Yes & No & Yes \\
\hline New components & 49 & 56 & 46 & $55^{* * *}$ & 44 & $55^{* * *}$ & 45 & $55^{* * * *}$ \\
\hline New design & 74 & 80 & 78 & $70 * *$ & 74 & 74 & 77 & $71 *$ \\
\hline New functions & 48 & $62 *$ & 40 & $60 * * *$ & 42 & $55^{* * * *}$ & 42 & $55^{* * * *}$ \\
\hline New materials & 52 & 50 & 48 & $56 * *$ & 48 & $56^{* *}$ & 48 & $56^{* * *}$ \\
\hline
\end{tabular}

Regarding the access to sources of external technology, Exhibit 8 shows the contingency indicators of the association between coopetition and different sources of external technology. First, the financial participation in R\&D firms that develop technological innovations is carried out by $28.4 \%$ of coopetition firms versus $4.8 \%$ of non-coopetition firms. Second, $23.86 \%$ of coopetition firms hire personnel with business R\&D experience versus $4.88 \%$ of non-coopetition firms. Coopetition firms also hire more frequently personnel with public R\&D experience (13.07\% vs. $1.78 \%)$, and outsource R\&D activities than non-coopetition firms (3.4\% vs. $1.2 \%)$. The stronger positive associations are for the financial participation in R\&D firms and the hire of R\&D personnel. R\&D outsourcing does not seem to be positively associated to coopetition.

\begin{tabular}{|c|c|c|c|c|}
\hline \multicolumn{5}{|c|}{$\begin{array}{l}\text { Exhibit 8. Contingency Indicators of Association between Coopetition and } \\
\text { Access to External Knowledge }\end{array}$} \\
\hline & $\begin{array}{l}\text { Financial } \\
\text { participation in } \\
\text { R\&D firms }\end{array}$ & $\begin{array}{l}\text { Personnel hired } \\
\text { with private } R \& D \\
\text { experience }\end{array}$ & $\begin{array}{l}\text { Personnel hired } \\
\text { with public R\&D } \\
\text { experience }\end{array}$ & $\begin{array}{c}R \& D \\
\text { outsourcing }\end{array}$ \\
\hline $\begin{array}{l}\text { Chi-square Pearson } \\
\text { Continuity Correction } \\
\text { Likelihood Ratio } \\
\text { Phi Statistic }\end{array}$ & $\begin{array}{r}185,261^{* * *} \\
180,706^{* * * *} \\
100,190^{* * *} \\
0.166 * * *\end{array}$ & $\begin{array}{r}121,217 * * * \\
117,519 * * * \\
70,136 * * * \\
0.135 * * *\end{array}$ & $\begin{array}{r}107,270 * * * \\
101,796 * * * \\
51,113 * * * \\
0.127 * * *\end{array}$ & $\begin{array}{r}6,688^{*} \\
5,035^{*} \\
4,629^{*} \\
-0.032^{*}\end{array}$ \\
\hline
\end{tabular}

$+\mathrm{p}<0.1 \quad * \mathrm{p}<0.05 \quad * * \mathrm{p}<0.01 \quad * * * \mathrm{p}<0.001$

Exhibit 9 assesses the association between coopetition and the use of different flexible production technologies: Computer-Aided Design (CAD), Local Area Networks (LAN), Numerically Controlled Machine Tools (NCMT), Robots, and Flexible Manufacturing Systems (FMS). The percentage of coopetition firms that use these technologies is higher, and all the differences are statistically significant (p<0.001): CAD (68.75\% vs. $37.92 \%)$, LAN (59.09\% vs. $24.41 \%)$, NCMT (68.6\% vs. $49.22 \%)$, Robots $(58.52 \%$ vs. $27.82 \%)$, and FMS (54.54\% vs. $24.51 \%)$.

\begin{tabular}{|c|c|c|c|c|c|}
\hline \multicolumn{6}{|c|}{$\begin{array}{l}\text { Exhibit 9. Contingency Indicators of Association between Coopetition and } \\
\text { Flexible Production Technology }\end{array}$} \\
\hline & CAD & LAN & NCMT & Robots & FMS \\
\hline & **** & 108,9 & 25,1 & $78,997 * * *$ & 81,69 \\
\hline Continuity Correction & $67,289 * * *$ & 107,111 *** & $24,401 * * *$ & $77,502 * * *$ & $80,112^{* * * *}$ \\
\hline Likelihood Ratio & $66,571 * * *$ & $92,451 * * *$ & $25,752 * * *$ & $70,101 * * *$ & $70,111 * * *$ \\
\hline Phi Statistic & $0.102 * * *$ & $0.128 * * *$ & $0.062 * * *$ & $0.109 * * *$ & $0.111 * * *$ \\
\hline
\end{tabular}

Finally, Exhibit 10 shows the results of the logistic regression that tests the hypotheses. The percent-age of temporary employment is positively related to coopetition $(\hat{a}=1.331 ; \mathrm{p}<0.05)$ which supports hypothesis $\mathrm{H} 1$; the hire of $\mathrm{R} \& \mathrm{D}$ employees is only marginally related to coopetition ( $\hat{\mathrm{a}}=0.395 ; \mathrm{p}<0.1$ ) which does not support hypothesis $\mathrm{H} 2$; R\&D outsourcing is not related to coopetition ( $\hat{a}=-0.783 ; p>0.1$ ) which does not support hypothesis $\mathrm{H} 3$; the financial participation in R\&D firms is positively 
related to coopetition ( $\hat{\mathrm{a}}=0.537$; $\mathrm{p}<0.05$ ) which supports hypothesis $\mathrm{H} 4$; and the technological cooperation with customers $(\hat{a}=1.097 ; \mathrm{p}<0.01)$ and suppliers $(\hat{\mathrm{a}}=1.507 ; \mathrm{p}<0.01)$ are positively related to coopetition which supports hypotheses H5a \& H5b.

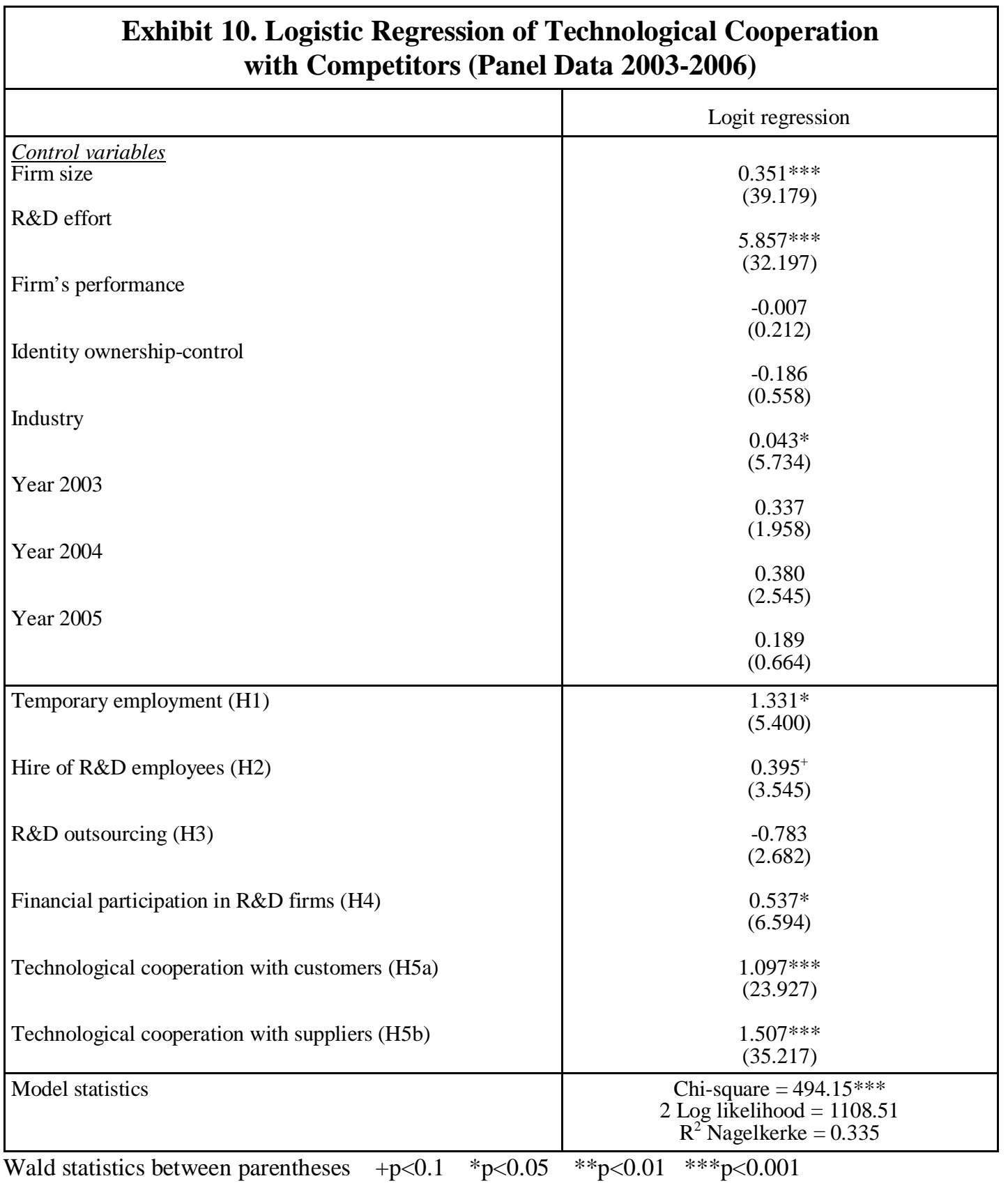

\section{DISCUSSION AND CONCLUSION}

Scholars suggest that coopetition is an intriguing phenomenon and deserves scholarly attention (Lado et al., 1997), and the managerial trend shows increased tendency to form cooperative ties with competitors and network-based competition among firms. Yet, little empirical research has addressed the determinants of technological coopetition and its implications (Ketchen et al., 2004). By empirically examining how external workplace and technology flexibilities are related to technological coopetition, we believe that this study advances our understanding of coopetition and suggests several possibilities for future research and managerial practice.

Two points are noteworthy based on our theory and data. First, external workplace flexibility is positively related to coopetition. One direct implication is that firms that have access to external sources of 
knowledge are in a better position to cooperate with competitors because they may perceive less risk involved in knowledge access and deployment in the network relationship. Second, technological flexibility from networking in the supply chain is also positively related to coopetition. Then, firms able to access technological advances in new technology-based firms and cooperate with customers and suppliers are also better prepared to deal with the uncertainty of technological developments with competitors. Executives need to consider how the different components in the organisational structure interface with the external environment, and they also need to understand the implications of different flexible dimensions for competitive behaviour.

Our result that coopetition only produces significant differences for the type of product innovation based on new functions contributes to the literature that finds a lesser impact of coopetition on the degree of product innovation novelty. Some studies find that different types of partners (except competitors) affect this degree of product innovation novelty. For instance, Nieto and Santamaría (2007) reveal that competitor collaboration has a negative impact on the degree of innovation. Management analysts do not view competitor collaboration as an appropriate instrument to achieve more novel innovations due to lack of trust and the fear of helping a rival. However, Tsai and Wang (2009) suggest that, depending upon the firm's internal R\&D investment, collaborating with competitors is a good choice for a firm's innovation performance. Firms with more efforts in internal R\&D usually exhibit stronger absorptive capacity (Cohen and Levinthal, 1990), enabling them to better incorporate and use new knowledge from collaboration with competitors for their own ends.

This study is exploratory but opens new venues for research. We do not claim for causality in the flexibility-coopetition relationship. Longitudinal studies should provide directions for causality because some flexibility dimensions could be caused by coopetition. The study of moderator effects could also focus the analysis on the impact of other flexibility dimensions on coopetition.

\section{ACKNOWLEDGEMENTS}

The authors greatly appreciate the financial support of the Spanish Ministry of Science and Innovation (Grant SEJ2007-62964/ECON), and the access to the Survey of Business Strategies provided by the SEPI Foundation and the Spanish Ministry of Industry. 


\section{REFERENCES}

Bierly III, P., Damanpour, F. and Santoro, M. (2009), The application of external knowledge: Organizational conditions for exploration and exploitation, Journal of Management Studies, 46, pp. 481509.

Brockhoff, K. (2003), Customers' perspectives of involvement in new product development, International Journal of Technology Management, 26, pp. 464-481.

Cohen, W. and Levinthal, D. (1990), Absorptive capacity: a new perspective on learning and innovation, Administrative Science Quarterly, 35, pp. 128-152.

Gnyawali, D. and Madhavan, R. (2001), Cooperative networks and competitive dynamics: A structural embeddedness perspective, Academy of Management Review, 26, pp. 431-445.

Gnyawali, D., He, J. and Madhavan, R. (2006), Impact of coopetition on firm competitive behaviour: An empirical examination, Journal of Management, 32, pp. 507-530.

Grant, R. (1996), Toward a knowledge-based theory of the firm, Strategic Management Journal, 17, pp. 109-122.

Gupta, S., Woodside, A., Dubelaar, C. and Bradmore, D. (2009), Diffusing knowledge-based core competencies for leveraging process organizations (KPOs) in pharmaceutical networks, Industrial Marketing Management, 38, pp. 219-27.

Huang, Y., Chung, H. and Lin, C. (2009), R\&D sourcing strategies: Determinants and consequences, Technovation, 29, pp. 155-69.

Inkpen, A. and Pien, W. (2006), An examination of collaboration and knowledge transfer: ChinaSingapore Suzhou industrial park, Journal of Management Studies, 43, pp. 779-811.

Kalleberg, A. and Mardsen, P. (2005), Externalizing organizational activities: Where and how U.S. establishments use employment intermediaries, Socio-Economic Review, 3, pp. 389-415.

Kessler, E., Bierly, P. and Gopalakrishnan, S. (2000), Internal vs. External learning in new product development: effects on speed, costs, and competitive advantage, $R \& D$ Management, 30, pp. 213-223.

Kessler, E. and Chakrabatri, A. (1996), Innovation speed: a conceptual model of context, antecedents, and outcome, Academy of Management Review, 21, pp. 1143-1191.

Ketchen, D., Snow, C. and Hoover, V. (2004), Research on competitive dynamics: Recent accomplishments and future challenges, Journal of Management, 30, pp. 779-804.

Lado, A., Boyd, N. and Hanlon, S. (1997), Competition, cooperation, and the search for economic rents: A syncretic model, Academy of Management Review, 22, pp. 110-141.

Martínez-Sánchez, A., Vela-Jiménez, M., Pérez-Pérez, M. and de-Luis-Carnicer, P. (2009), Interorganizational cooperation and environmental change: moderating effects between flexibility and innovation performance, British Journal of Management, 20, pp. 537-561.

Matusik, S. and Hill, C. (1998), The utilization of contingent work, knowledge creation, and competitive advantage, Academy of Management Review, 23, pp. 680-697.

Miller, D. and Chen, M.-J. (1996), The simplicity of competitive repertoires: An empirical analysis, Strategic Management Journal, 17, pp. 419-439.

Mol, M., Pauwels, P., Matthyssens, P. and Quintens, L. (2004), A technological contingency perspective on the depth and scope of international outsourcing, Journal of International Management, 10, pp. 287-305.

Nalebuff, B. and Brandenburger, A. (1996), Coopetition, Harper Collins Business, Philadelphia, PA.. 
Nesheim, T. (2003), Using external work arrangement in core value-creation areas, European Management Journal, 21, pp. 528-537.

Nesheim, T., Olsen, K. and Kalleberg, A. (2007), Externalizing the core: Firms' use of employment intermediaries in the information and communication technology industries, Human Resource Management, 46, pp. 247-264.

Nieto, M. and Santamaría, L. (2007), The importance of diverse collaborating networks for the novelty of product innovation, Technovation, 27, pp. 367-377.

Quinn, J. (2000), Outsourcing innovation: the new engine of growth, Sloan Management Review, 41, pp. 13-28.

Quintana-García, C. and Benavides-Velasco, C. (2004), Cooperation, competition, and innovative capability: A panel data of European dedicated biotechnology firms, Technovation, 24, pp. 927-938.

Ritala, P. and Hurmelinna-Laukkanen, P. (2009), What's in it for me? Creating and appropriating value in innovation-related coopetition, Technovation, 29, pp. 819-828.

Rothaermel, F. and Hess, A. (2007), Building dynamic capabilities: Innovation driven by individual, firm-, and network-level effects, Organization Science, 18, pp. 898-921.

Tether, B. (2002), Who co-operates for innovation, and why: An empirical analysis, Research Policy, 31, pp. 947-967.

Tsai, K. and Wang, J. (2009), External technology sourcing and innovation performance in LMT sectors: An analysis based on the Taiwanese Technological Innovation Survey, Research Policy, 38, pp. 518-526.

Watanabe, C. and Hur, J. (2004), Resonant R\&D structure for effective technology development amidst megacompetition: en empirical analysis of smart cooperative R\&D structure in Japan's transport machinery industry, Technovation, 24, pp. 955-969.

Wright, P. and Snell, S. (1998), Toward a unifying framework for exploring fit and flexibility in strategic human resource management, Academy of Management Review, 23, pp. 756-772.

Young, G., Smith, K. and Grimm, C. (1996), Austrian and industrial organization perspectives on firm -level competitive activity and performance, Organization Science, 7, pp. 243-254. 